\title{
Biogenic sediments from coastal ecosystems to beach-dune systems: implications for the adaptation of mixed and carbonate beaches to future sea level rise
}

\author{
Giovanni De Falco $^{1}$, Emanuela Molinaroli ${ }^{2}$, Alessandro Conforti ${ }^{1}$, Simone Simeone $^{1}$, and Renato Tonielli ${ }^{3}$ \\ ${ }^{1}$ Istituto per l'ambiente Marino Costiero CNR, Oristano, Italy \\ ${ }^{2}$ Dipartimento di Scienze Ambientali, Informatica e Statistica, Università Ca' Foscari, Venice, Italy \\ ${ }^{3}$ Istituto per l'ambiente Marino Costiero CNR, Naples, Italy \\ Correspondence to: Giovanni De Falco (giovanni.defalco@cnr.it)
}

Received: 25 January 2017 - Discussion started: 20 February 2017

Revised: 29 May 2017 - Accepted: 7 June 2017 - Published: 5 July 2017

\begin{abstract}
Coastal ecosystems produce and store carbonate particles, which play a significant role in the carbonate dynamics of coastal areas and may contribute to the sediment budget of adjacent beaches. In the nearshore seabed of temperate zones (e.g. Mediterranean Sea and South Australia), marine biogenic carbonates are mainly produced inside seagrass meadows. This study quantifies the contribution of biogenic sediments, mainly produced in Posidonia oceanica seagrass meadows and secondarily in photophilic algal communities, to the sediment budget of a Mediterranean beachdune system (San Giovanni beach, western Sardinia, western Mediterranean Sea). A set of geophysical, petrographic and sedimentological data was used to estimate the sediment volume and composition of the beach-dune system as a whole. The San Giovanni beach-dune system contains $3797000 \pm$ $404000 \mathrm{t}$ of sediment, $83 \%$ (3137000 $\pm 404000 \mathrm{t})$ of which is located in the coastal wedge, $16 \%(619000 \pm 88000 \mathrm{t})$ in the dune fields and $1 \%(41000 \pm 15000 t)$ in the subaerial beach. The sediments are composed of mixed modern bioclastic and relict bioclastic and non-bioclastic grains from various sources. The system receives a large input of modern bioclastic grains, mainly composed of rhodophytes, molluscs and bryozoans, which derive from sediment production of present-day carbonate factories, particularly $P$. oceanica seagrass meadows. Radiocarbon dating of modern bioclastic grains indicated that they were produced during the last $4.37 \mathrm{kyr}$. This value was used to estimate the longterm deposition rates of modern bioclastic sediments in the various beach compartments. The total deposition rate of modern bioclastic grains is $46000 \pm 5000$ t century $^{-1}$, mainly
\end{abstract}

deposited in the coastal wedge $\left(39000 \pm 4000\right.$ t century $\left.^{-1}\right)$ and dunes $\left(7000 \pm 1000\right.$ t century $\left.^{-1}\right)$, and $46000 \mathrm{t}$ represents $\sim 1.2 \%$ of the total beach-dune sediment mass. Carbonate production from coastal ecosystems was estimated to be $132000 / 307000$ t century $^{-1}, 28 \%(15 \% / 34 \%)$ of which is transported to the beach-dune system, thus significantly contributing to the beach sediment budget.

The contribution to the beach sediment budget represents a further ecosystem service, which our data can help quantify, provided by $P$. oceanica. The value of this sedimentsupply service is in addition to the other important ecological services provided by seagrass meadows. The dependence of the beach sediment budget on carbonate production associated with coastal ecosystems has several implications for the adaptation of mixed and carbonate beaches to the loss of seagrass meadows due to local impacts and the changes expected to occur over the next few decades in coastal ecosystems following sea level rise.

\section{Introduction}

Carbonate beaches are widespread in tropical areas and locally, bioclastic carbonate sands may also be the main component of sediments in beach-dune systems in the temperate zone (Short, 2000).

The sediment budget of beach-dune systems is mainly influenced by the supply and delivery of sediments from the land (fluvial, cliff erosion) and from the sea (nearshore). The 
latter involves the reworking and winnowing of seabed sediments and sediments derived from biogenic carbonate production associated with marine coastal ecosystems (GómezPujol et al., 2013). In areas where supply from the land is scarce or absent, marine sources of sediment became more important for the maintenance of the coastal system, and beaches become progressively more calcareous (Bird, 2008). This is the case with the coasts of southern and southwestern Australia, the largest temperate carbonate province in the world, where carbonates produced along the shelf and in seagrass meadows are transported landward, supplying extensive beach-dune systems (Short, 2000).

Modern biogenic sedimentation along continental shelves is documented in both tropical and temperate environments (Tecchiato et al., 2015; Yamano et al., 2015; Short, 2010; De Falco et al., 2011; Ryan et al., 2008; Harney and Fletcher III, 2003). Along shores bordered by reefs or atolls, coral-based ecosystems such as barrier reefs and lagoons are a source of carbonates for beaches (Yamano et al., 2002). In temperate zones, marine biogenic carbonate sediments are often produced in the seagrass meadows that colonise the nearshore area (De Muro et al., 2016; Mazarrasa et al., 2015; Short 2010; De Falco et al., 2008; Sanderson and Eliot, 1999).

In the Mediterranean Sea the main marine carbonate factories in the infralittoral zone are Posidonia oceanica meadows, which cover about $1.5 \%$ of the total Mediterranean Sea sediment surface (Pasqualini et al., 1998) and occur in 16 Mediterranean countries (Giakoumi et al., 2013).

Sediments accumulating inside the meadows generally show a high percentage of biogenic carbonate particles produced by the biota associated with the seagrass ecosystem, such as coralline algae, foraminifers, gastropods, bivalves, serpulid polychaetes, bryozoans and echinoids (Fornós and Ahr, 1997).

Several authors have estimated carbonate production in $P$. oceanica meadows using various approaches. Estimates based on the rhizome growth rate of meadows located in the northern sector of the Gulf of Oristano (western Sardinia, Italy) indicate that carbonate production is in the range of 390 to $1147 \mathrm{~g} \mathrm{DW} \mathrm{CaCO}_{3} \mathrm{~m}^{-2} \mathrm{a}^{-1}$ (De Falco et al., 2008). These values are amongst the highest for seagrass ecosystems (Gacia et al., 2003) and lie within the range calculated for coral reefs (1160 g DW g DW CaCO $3 \mathrm{~m}^{-2} \mathrm{a}^{-1}$, Milliman and Droxler, 1996). The analysis of a core collected from a $P$. oceanica meadow near Port Lligat (Cadaqués, Girona, northwestern Spain) enabled skeletal carbonate accumulation rates to be estimated at $452.9 \pm 15.5 \mathrm{~g} \mathrm{DW} \mathrm{CaCO}_{3} \mathrm{~m}^{-2} \mathrm{a}^{-1}$ (Serrano et al., 2012). This value is consistent with those estimated for western Sardinia (De Falco et al., 2000, 2008). At a global level, carbonate production from seagrass meadows is estimated at $1050 \mathrm{~g} \mathrm{DW} \mathrm{CaCO}_{3} \mathrm{~m}^{-2} \mathrm{a}^{-1}$ (Mazzarrasa et al., 2015, and references therein). Those estimations considered the burial rate of biogenic carbonate to the carbonate production, with the assumption that no deposition of carbonate sediments of external origin occurred. Con- versely, Canals and Ballesteros (1997) evaluated the carbonate production from a Posidonia oceanica meadow as 60$70 \mathrm{~g} \mathrm{DW} \mathrm{CaCO}_{3} \mathrm{~m}^{-2} \mathrm{a}^{-1}$, considering the production related to the epiphytes, which were scraped from the blades using a razor blade. Their method clearly underestimates the bulk production because they did not take into account the fauna associated with the rhizome compartment, which is generally composed by many carbonate-producing organisms (Como et al., 2008).

The Posidonia oceanica seagrass meadows are very widespread near the shore. For this reason, P. oceanica meadows are considered the main carbonate factory of the Mediterranean inner shelf (Canals and Ballesteros, 1997; Fornós and Ahr, 1997, 2006; De Falco et al., 2008, 2011; Mateu-Vicens et al., 2012).

Biogenic carbonate production is also associated with photophilic algal communities colonising nearshore rocky bottoms. The average production rate associated with photophilic algae at a selection of sites in the western Mediterranean was estimated at $289 \mathrm{~g} \mathrm{DW} \mathrm{CaCO}_{3} \mathrm{~m}^{-2} \mathrm{a}^{-1}$ (Canals and Ballesteros, 1997).

The carbonate sediments produced inside these coastal ecosystems nourish beaches and coastal systems along Mediterranean shores (De Falco et al., 2003; De Falco et al., 2008; Gómez-Pujol et al., 2013; Vacchi et al., 2016). This has been observed in the Balearic Islands (Gómez-Pujol et al., 2013), western Sardinia (Tigny et al., 2007; De Falco et al., 2003) and in pocket beaches in southern Corsica (De Muro and De Falco, 2010). Mixed (mixture of siliciclastic and carbonate grains) and carbonate beaches are widespread at many other Mediterranean sites (e.g. the Ionian coast of Puglia, South Italy, Barsanti et al., 2011; and northern Sardinia, Campus et al., 2008), and they may be threatened by alteration of carbonate sediment budgets coupled with sea level rise. Carbonate sediment budgets can be impacted by the general decline of coastal ecosystems following local impacts, seawater acidification and climate change (Duarte et al., 2013; Mazarrasa et al., 2015; Wycott et al., 2009).

Seagrass is generally known as an ecosystem engineer as it can modify the abiotic environment and contribute to sedimentation and sediment modification (Borg et al., 2005). Several studies have shown that sediment retention and wave attenuation are probably the most valuable ecosystem services provided by $P$. oceanica meadows (Vassallo et al., 2013, and references therein). However, little attention has been paid to the meadows' role as contributors to long-term beach sediment budgets because no quantitative computation of the exchange and deposition rates of carbonate sediments from $P$. oceanica meadows to beach-dune systems has yet been made.

The aim of this study was to compare the long-term deposition rate of biogenic carbonate sediments in a Mediterranean beach-dune system to the estimated carbonate production rates of adjacent carbonate factories. For the purposes of this study we define the beach-dune system as the 


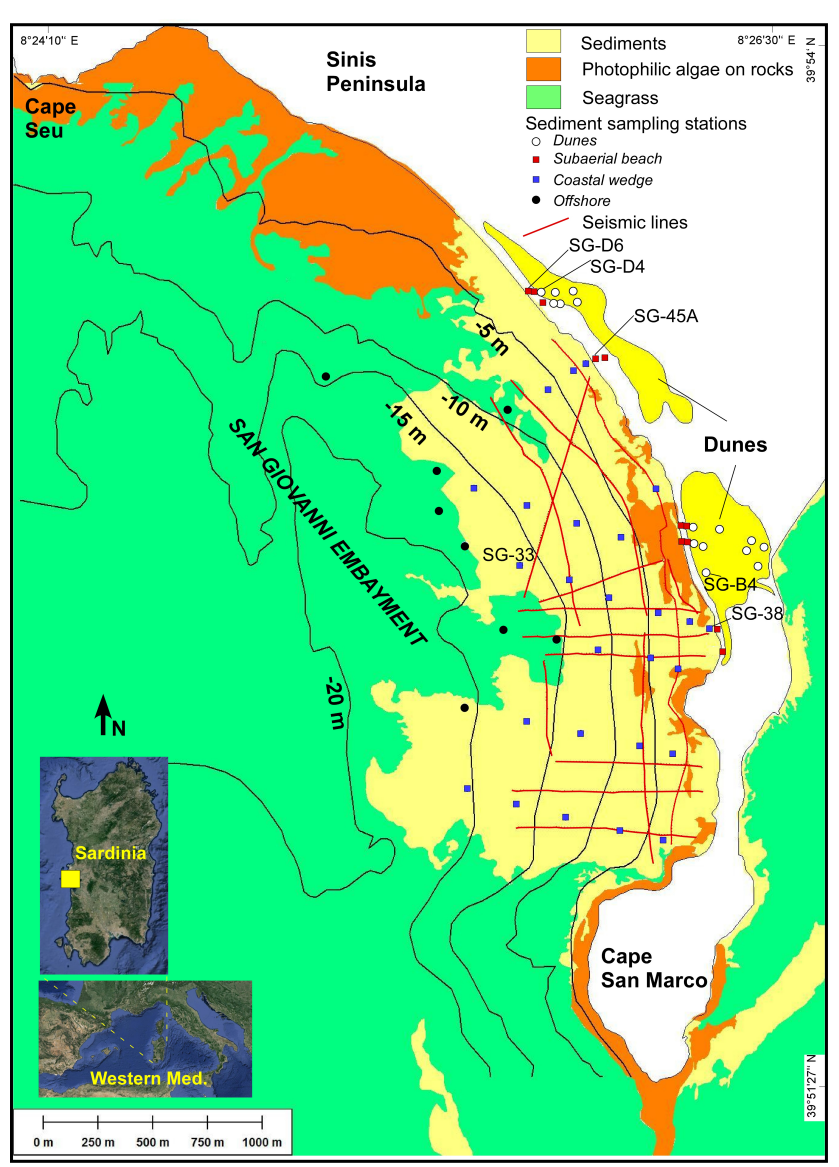

Figure 1. Schematic geomorphological map of the study area showing the location of sampling points along the Sinis Peninsula in the San Giovanni embayment and distribution of $P$. oceanica meadows growing on hard ground and sedimentary substrates. The labelled points correspond to samples used for radiocarbon analysis (see Table 1). Red lines are seismic profiles.

coupling of the beach system (following the definition sketch proposed by Short, 1999) and the dunes. In particular, the beach system is composed of the subaerial beach and the coastal wedge, which includes the surf zone and the area near the shore (Short, 1999). The study area is far from terrigenous sources of sediments and sediment supply is mainly of marine origin. It is thus a good model system to estimate carbonate sediment exchanges between coastal ecosystems and beaches and dunes. The resilience of such carbonate beachdune systems to climate and sea level changes expected in the near future is discussed.

\section{Study site}

The beach-dune system analysed in this study is located in the bay of San Giovanni, a large embayment located on the Sinis Peninsula on the central-western coast of Sardinia (western Mediterranean Sea) (Fig. 1).
The embayment is $4 \mathrm{~km}$ wide, running from Cape Seu to Cape San Marco, and is characterised by cliffs alternating with sandy beaches. The geological setting of the Sinis Peninsula includes a sequence of volcanic and sedimentary rocks (marls, sandstone and limestone) dating from the Neogene to the Quaternary. The cliffs along the San Giovanni embayment are composed of Miocene limestone and marls, early Pliocene sandstones, Pliocene basalts and a late Pleistocene succession composed of sandy to gravelly shallowmarine, coastal aeolian and alluvial fan deposits (Andreucci et al., 2009).

The seabed map, in Fig. 1, shows that the seabed in the shallower northern sector of the bay and around the capes is mainly rocky, while unconsolidated sedimentary deposits are present in the central sector and seagrass meadows are widespread along the outer sector. Inland, two dune fields have been mapped (geological map of Sardinia on a scale of $1: 25000$ available on the portal of the Sardinia Regional Administration http://www.sardegnageoportale.it/ disclaimer.html). The sediment grain size of the San Giovanni beach ranges from fine-medium sand to coarse sand with biogenic carbonate content varying from 30 to $90 \%$ of dry weight (De Falco et al., 2003). Based on sediment composition, this beach can be classified as mixed bioclasticsiliciclastic.

The seagrass meadows are composed of the endemic Mediterranean species Posidonia oceanica. Meadow distribution is influenced by substrate morphology. The plant colonises rocky and sandy substrates, forming a matte $\sim 50 \mathrm{~cm}$ thick, with frequent inter-matte channels inside the meadow and associated bioclastic sediments (De Falco et al., 2003). The nearshore rocky outcrops are colonised by photophilic algae (De Falco and Piergallini, 2003).

In the San Giovanni embayment, $P$. oceanica may form seagrass berms resulting from the accumulation of litter (leaves and rhizomes) and sediments at the extreme landward edge of wave influence (Simeone and De Falco, 2012; Simeone et al., 2013).

The prevailing winds are mainly from the northwest (mistral), often in the form of severe storms, especially during winter. In autumn and winter, southwestern winds (libeccio) are also important (Corsini et al., 2006). The tides are negligible, with a maximum range of $<0.2 \mathrm{~m}$ (Cucco et al., 2006). Waves more than $3 \mathrm{~m}$ high occur along the prevalent incoming axis, located in the northwestern sector between 280 and $330^{\circ}$.

The morphodynamics of the San Giovanni beach are conditioned by the occurrence of rocky outcrops that influence wave run-up and the interactions between the surf zone and foredunes in the various beach sectors (Simeone et al., 2014). The longshore current induced by waves during mistral wind events follows a cell circulation pattern (Balzano et al., 2013). The cliffs and the submerged rocky platforms are the main factors controlling subaerial beach height and beach dynamics (Simeone et al., 2014). 


\section{Methods}

\subsection{Geophysical data}

The morphology of the beach-dune system was analysed using digital terrain models (DTMs) of the subaerial and submerged sectors. The DTM of the subaerial beach, dune fields and back-barrier areas was derived from lidar data, with a spatial resolution of $1 \mathrm{~m}$ and a vertical resolution of $0.15 \mathrm{~m}$ (available on the portal of the Sardinia Regional Administration http://www.sardegnageoportale.it/disclaimer.html), and differential GPS real-time kinematic (RTK) data, with a vertical resolution of $0.15 \mathrm{~m}$. The DTM of the marine area was derived from multibeam echosounder (MBES) data, acquired using a Reson SeaBat 7125 operating at a sonar frequency of $400 \mathrm{kHz}$, which yielded a DTM with a spatial resolution of $1 \mathrm{~m}$ and a vertical resolution of $0.01 \mathrm{~m}$. These data were integrated with single-beam echosounder (SBES) data, acquired using a Knudsen 320BP operating at a sonar frequency of $28 / 200 \mathrm{kHz}$. Data were acquired along transects perpendicular and parallel to the shoreline and were interpolated to obtain a DTM with a grid resolution of $20 \mathrm{~m}$.

The sediment thickness of the submerged sector (coastal wedge) of the beach was determined by collecting $\sim 14 \mathrm{~km}$ of very-high-resolution seismic lines using a sub-bottom Chirp EdgeTech profiler 3100P at 4-24 kHz (Fig. 1). The vertical resolution of the seismic data was $0.1 \mathrm{~m}$.

\subsection{Sedimentological data}

The sedimentological dataset used in this study was obtained from a number of sediment transects: four transects in the dunes (15 sediment samples), six transects in the subaerial beach (11 sediment samples) and six transects in the coastal wedge (26 sediment samples). In addition, eight offshore sediment samples were taken (Fig. 1). The marine sediments were collected using a Van Veen grab. Authorisation for sediment sampling was granted by the Oristano department of the Italian Coast Guard and the marine protected area known as Penisiola del Sinis - Isola di Mal di Ventre.

The grain size of the sampled sediments was determined by dry sieving ( $1 / 2$ phi intervals). Silt and clay-size particles were not analysed because they generally form a small proportion of the sediment $(<5 \%)$ in this high-energy environment (Table S1 in the Supplement). The carbonate content was determined using a Dietrich-Fruhling calcimeter.

\subsection{Petrographic analysis}

The collected samples were analysed using a stereomicroscope, after which they were injected with epoxy resin, cut into thin sections and examined under a polarising microscope. Statistical analysis of petrographic data was based on point-counting following the method described by Flügel (1982). A minimum of two 300-point counts were performed on separate portions of each thin section to reduce errors
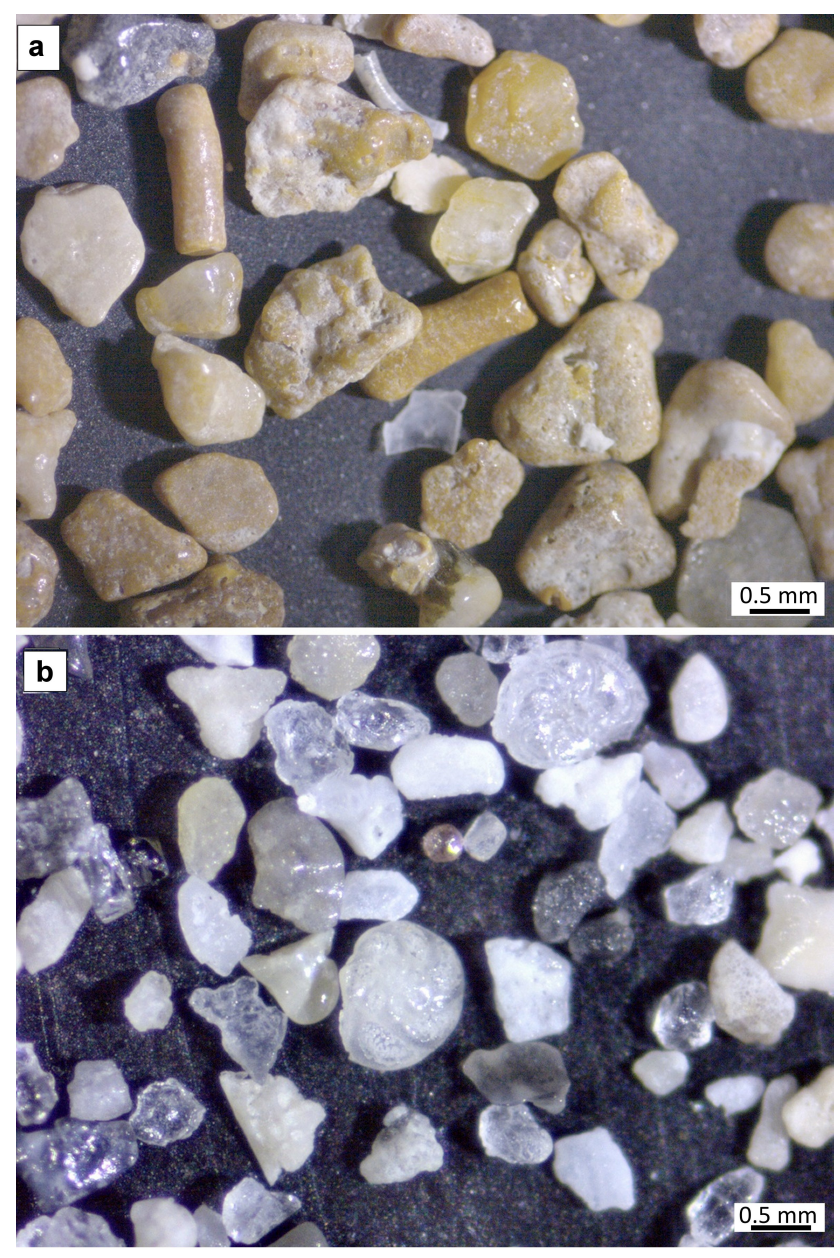

Figure 2. Photographs of two sediment samples. (a) Relict grains, highly abraded, including both Fe-stained bioclasts and lithoclasts (sample SG-18, from offshore); (b) modern bioclastic grains, slightly abraded, generally unabraded and biofragmented (sample SG-28, from the coastal wedge).

linked to sediment heterogeneity. We calculated the percentages of grain types among the samples, tabulating bioclastic and non-bioclastic components (Table S2).

Bioclastic components are made up of calcite and micrite assemblages of molluscs (bivalves and gastropods), calcareous algae (rhodophytes), benthic foraminifers, echinoids, bryozoans and brachiopods (Table S2). Non-bioclastic grains are made of siliciclastic and unidentified grains.

Following the suggestions of James et al. (1997), we sought to classify the bioclastic grains by morphology, colour and abrasion (Fig. 2). Our sediments are palimpsest, consisting of material currently being produced and deposited in the basin (Holocene), as well as elements deposited previously. Based on the methodology of bioclastic grain classification proposed by James et al. (1997) and Rivers et al. (2007), we were able to recognise the grains and classify them as relict or modern bioclastic grains (MBGs). 
Relict grains (Fig. 2a) are (i) highly abraded (rounded and to some degree polished when compared with equivalent modern bioclastic grains) (ii) stained yellow-brown due to the presence of iron oxides or other diagenetic phases, and (iii) filled in (where skeletal pores are present) with siltsize carbonate particles as well as micrite. The physical and chemical alteration of relict grains makes it difficult or impossible to recognise their biogenic components. In James et al. (1997), relict particles were dated to between 10000 and 36000 yr BP.

Modern bioclastic grains originate from the carbonate factory of the infralittoral zone. The grains can be slightly abraded, light grey to buff-coloured skeletal particles. Some of them show (i) lack of brightness, (ii) rounding of skeletal edges and (iii) lack of well-defined fine-scale skeletal surface structures (Fig. 2b). Sedimentary recycling is particularly effective during the migration of the coastal system via barrier rollover to the dune system. Some of the grains are also fine sand bioclasts that show little or no sign of alteration or reworking. Major sources of the regional carbonate assemblage include bivalves, gastropods, rhodophytes, bryozoans, brachiopods and benthic foraminifers.

Six modern bioclastic carbonate samples were radiocarbon dated (Table 1). The sediment samples were rinsed in Milli-Q water, and they were inspected under a stereomicroscope to select shells and shell fragments from the mixed samples.

The radiocarbon measurements were carried out by the standard method, at the Beta Analytic Radiocarbon Dating, Miami, Florida (USA). Acid etch (hydrochloric acid, $\mathrm{HCl})$ was applied as a pretreatment. The radiocarbon ages were calibrated considering a reservoir effect of the western Mediterranean Sea (Delta-R $=46 \pm 40$ ). Applicable calendar-calibrated results were calculated using Marine13 (Reimer et al., 2013; Talma and Vogel, 1993). The results are presented as conventional and calibrated ages (Table 1).

The similarities and differences between sediments from the dunes, subaerial beach, coastal wedge and offshore sediments were determined using multivariate statistics. Factor analysis was applied to petrographic and grain size data, previously transformed by the ranking method.

\subsection{Sediment budget}

The sediment volume of the beach-dune system was estimated by subdividing it into three compartments: the dune fields, the subaerial beach and the coastal wedge (Fig. 3). The toe of the foredune separates the dunes from the subaerial beach, whereas the shoreline separates the subaerial beach from the coastal wedge. The offshore limit of the coastal wedge is a morphological step visible in the DTM (Figs. 3 and 4).

In order to compute the volume of the dunes and subaerial beach, we subtracted the grid of the underlying substrate surface from the grid of the dune and subaerial beach surface.

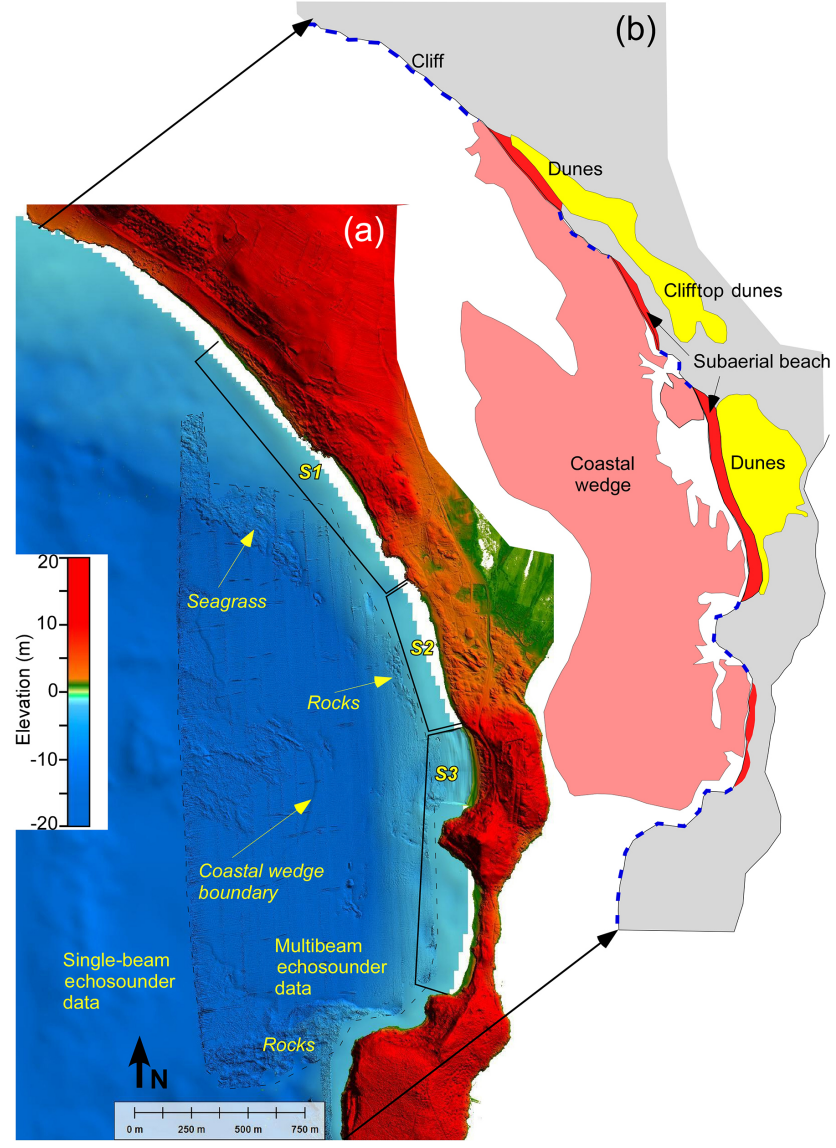

Figure 3. Geomorphological features of the study area shown in Fig. 1. (a) Digital terrain models (DTMs) of the emerged and submerged sectors. The DTM of the marine area is derived from multibeam echosounder (MBES) data integrated with single-beam echosounder (SBES) data. Shaded relief map of the submerged area showing the coastal wedge, seagrass meadows and rocky outcrops. The DTM of the inland area was derived from lidar data. S1 is the northern sector of the coastal barrier system. S2 is the central sector and S3 is the southern sector. Panels (b) shows the representation of the beach-dune system compartments: dune fields (yellow), subaerial beach (red) and coastal wedge (pink).

Figure 4 shows a schematic cross section with the surfaces used for volume estimation.

The morphology of the substrate underlying the dunes and the subaerial beach was interpolated, as shown in Fig. 4, by using the elevation data of the boundary of the dunes and adding the elevation data of the rocky outcrops present on the subaerial beach and along the shoreline. Those data were interpolated to obtain a grid of the basal surface of the sedimentary body (the dashed red line in Fig. 4). This surface was subtracted from the grid of the terrain surface, available from the DTM (lidar and RTK data), in order to compute the volume using the Global Mapper 13 software package. The volume estimation margin of error was computed consider- 
Table 1. Radiocarbon datings for various carbonate particles. Locations of sampling points are shown in Fig. 1.

\begin{tabular}{llllll}
\hline Sample ID & Sample location & $\begin{array}{l}\text { Conventional } \\
\text { age }(\mathrm{yr} \mathrm{BP})\end{array}$ & $\begin{array}{l}\delta^{13} \mathrm{C} \\
(\% o)\end{array}$ & $\begin{array}{l}\delta^{18} \mathrm{O} \\
(\% o)\end{array}$ & $\begin{array}{l}\text { Calibrated } \\
\text { age (cal yr BP) }\end{array}$ \\
\hline SG-45A & Subaerial beach & $1050 \pm 30 \mathrm{BP}$ & 2.3 & 0.7 & Cal BP 660 to 510 \\
SG-D4 & Dunes & $4320 \pm 30 \mathrm{BP}$ & 2.1 & 1.1 & Cal BP 4510 to 4245 \\
SG-D6 & Subaerial beach & $1970 \pm 30 \mathrm{BP}$ & 1.7 & 1.1 & Cal BP 1580 to 1355 \\
SG-38 & Coastal wedge & $1120 \pm 30 \mathrm{BP}$ & 2.4 & 0.7 & Cal BP 705 to 550 \\
SG-33 & Coastal wedge & $1190 \pm 30 \mathrm{BP}$ & 2.7 & 1.8 & Cal BP 780 to 630 \\
SG-B4 & Dunes & $1020 \pm 30 \mathrm{BP}$ & 1.6 & 1.9 & Cal BP 645 to 495 \\
\hline
\end{tabular}

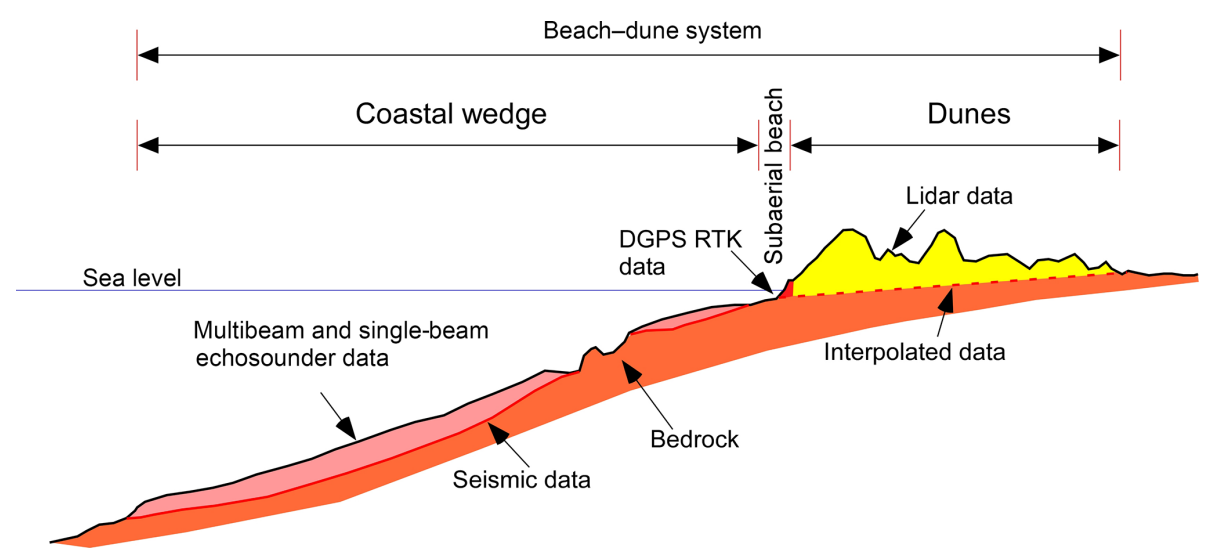

Figure 4. Beach profile showing the various layers used for sediment volume computation and the methods adopted for determination of the surface elevation.

ing a vertical variability of $\pm 0.15 \mathrm{~m}$, based on the vertical resolution of the lidar and RTK data.

The sediment thickness of the coastal wedge was obtained from the isopach map, derived in turn from the analysis of seismic lines using the GeoSuite software package. The spatial limit of the coastal wedge was mapped using data from the MBES survey and seabed mapping data (occurrence of rocky outcrops, Fig. 3). The DTM derived from the MBES data made it possible to identify the seaward limit of the coastal wedge, which is characterised by a morphological step (Fig. 3). The sediment volume estimation margin of error was based on the vertical resolution of the seismic data used for surface interpolation $( \pm 0.1 \mathrm{~m})$.

Sediment volume data were converted into sediment mass, adopting a porosity value of 0.3 and the density of calcite $\left(2.71 \mathrm{t} \mathrm{m}^{-3}\right)$. Based on petrographic analysis, the mass of modern carbonate bioclastic sediments was estimated for the different beach compartments (dunes, subaerial beach and coastal wedge). The deposition rates of modern carbonate bioclastic grains were computed considering a span of ages from approximately 0.5 to $4.4 \mathrm{ka} \mathrm{BP}$, based on radiocarbon dating of bioclastic grains (Table 1).

Carbonate sediment production in adjacent carbonate factories, i.e. the Posidonia oceanica seagrass meadows and the photophilic algal communities, was estimated by considering their surface area and the production rates reported in the lit- erature (De Falco et al., 2008 and Serrano et al., 2012, for $P$. oceanica meadows; Canals and Ballesteros, 1997, for photophilic algae).

\section{Results}

\subsection{San Giovanni beach-dune system morphology and stratigraphy}

The morphology of the beach-dune system of the San Giovanni embayment is mainly determined by the presence of rocky outcrops in the back-barrier region and along the shoreface.

The northern sector of the beach-dune system (S1, Fig. 3) includes a dune field, beaches located at the foot of cliffs and a narrow coastal sedimentary wedge delimited offshore by a rocky outcrop. The dune field is partially connected to the beach in the north, while it consists of clifftop dunes in the south.

The cliffs are vertical, $10 \mathrm{~m}$ high and carved out of the Pleistocene sedimentary formations (sandstones and limestones). At the foot of the cliffs the beaches are embayed between rocky headlands. The cliffs evolved in the historical period, as revealed by the presence of Roman tombs in the collapsed blocks (Acquaro, 1995). The sedimentary coastal 
wedge is located between the shoreline and a depth of $7 \mathrm{~m}$, at which the bedrock, partially colonised by Posidonia oceanica seagrass, crops out extensively. Bars are present along the submerged beaches.

Along the central sector of the beach-dune system (S2, Fig. 3), the dune field extends inland for about $500 \mathrm{~m}$. The dunes are partially vegetated, and parabolic dunes with blowouts are also present. The beach extends from the foredune to the foreshore where the bedrock crops out. The bedrock extends offshore, from the shoreline to a depth of $5 \mathrm{~m}$. The coastal wedge extends from the seaward limit of the rocky outcrop $(5 \mathrm{~m})$ to the $15 \mathrm{~m}$ depth line, marked by a clear break in the slope, which is visible in the DTM based on MBES surveys (Figs. 3, 5).

In the southern sector (S3, Fig. 3) the dunes are deposited on a scarp lying on marls dated to the upper Miocene. The lithology prevents the preservation of vertical cliffs, favouring, instead, the formation of $15 \mathrm{~m}$ high seaward-sloping talus deposits that have resulted from slumping. Dunes have developed on the steep substrate, with the beach connected to the toe of the dunes. The coastal wedge is in continuity with the beach, down to a rocky outcrop located at around 7-8 $\mathrm{m}$ depth. In this area there are several parallel bars. In the offshore sector, the coastal wedge is depth-limited by a break in the slope at $15 \mathrm{~m}$ depth.

The seismic surveys enabled assessment of the coastal wedge's thickness and stratigraphy (Fig. 5), finding variable thicknesses, up to a maximum of about $3 \mathrm{~m}$, depending on the morphology of the rocky substrate, which determines the space available for sediments (Fig. 5). To the north, several rocky outcrops limit the coastal wedge to small depositional areas (Line L1). In the central sector the coastal wedge lies on the seaward side of a very shallow rocky outcrop of the substrate (Line L2), whereas to the south a major rocky outcrop clearly separates the submerged beach with bars from the deeper portion of the coastal wedge (Line L3).

\subsection{Petrographic features of the mixed sediments}

The dunes and coastal wedge sediments are mainly bioclastic medium-fine sands $\left(\mathrm{CaCO}_{3} 75 \pm 12 \%\right.$ and $67 \pm 11 \%$ respectively), whereas the subaerial beach sediments are mixed coarse sands $\left(\mathrm{CaCO}_{3} 44 \pm 18 \%\right.$ ) (Table S1). The investigated mixed deposits include bioclastic and non-bioclastic components in highly variable proportions (Table S2).

Modern bioclastic grains, moderately abraded and unabraded, are generally found in all components of the beach-dune system (range 33-53\%) and are particularly abundant in the coastal wedge $(53 \%)$ and dunes $(46 \%)$ (Fig. 6a). Relict bioclasts, characterised by coarse sand to very fine granule-size skeletal particles that are highly abraded, rounded and heavily stained with iron oxides, are more abundant in the offshore samples $(29 \%)$ outside the beach-dune system (Fig. 6b).
Non-bioclastic components account for most of the subaerial beach's sedimentary facies $(61 \%)$, while they are subordinated to the bioclastic components in the other compartments (Fig. 6c).

We grouped siliciclastic and unidentified grains under non-bioclastic inputs. Siliciclastic components are represented mostly by well-sorted, medium- to coarse-grained well-rounded quartz grains. Other components include medium- to coarse-grained lithic fragments, whose origin is sedimentary, plutonic, volcanic and metamorphic. Unidentified grains were not readily identifiable under the binocular microscope due to either (i) extreme diagenetic alteration or secondary calcification and (ii) severe physical abrasion or fragmentation.

Modern bioclastic grains are mainly derived from coralline algae and molluscs, followed by bryozoans, brachiopods, benthic foraminifers and echinoids (Fig. 7) (Table S2). Consequently, the carbonate factory is characterised by rhodophytes and molluscs since these are the most important carbonate sediment-producing biota (Nelson, 1988).

The radiocarbon dating of six samples of modern bioclastic grains is reported in Table 1 . The oldest grain was dated to $4510-4245$ calibrated years BP, whereas the most recent grain was dated to $645-495$ calibrated years BP.

\subsection{Multivariate statistics}

Factor analysis was applied to petrographic and grain size data in order to reduce a large number of variables to a few uncorrelated variables. Factor analysis showed that the investigated deposits are readily identified from the considered variables (Fig. 8). The first three factors explain $\sim 74 \%$ of the variance of the samples, (factor 1, $46 \%$; factor $2,18 \%$; factor $3,10 \%$ ).

The beach-dune system compartments are clearly separated in the plot of the first and second factors (Fig. 8). Factor 1 is correlated with coarse grain size and relict grains, which are the main components of offshore and subaerial beach samples, and is inversely correlated with benthic foraminifers, MBGs and fine sands, which are more abundant in dunes and the coastal wedge. Factor 2 provides further separation of coastal wedge and offshore samples and subaerial beach-dune samples, the former characterised by rhodophytes, brachiopods and medium grain-size, and the latter by molluscs, bryozoans and fine grain-size (Fig. 8).

\subsection{Sediment budget}

The volume of sediment allocated to the three compartments of the beach-dune system (dunes, subaerial beach and coastal wedge) was computed (Table 2). The entire system has $\sim 2 \times 10^{6} \mathrm{~m}^{3}$ of sediment, of which $1667000 \pm$ $160000 \mathrm{~m}^{3}$ (83\% of the total) is in the coastal wedge, $330000 \pm 47000 \mathrm{~m}^{3}(16 \%)$ is in the dunes and only $22000 \pm$ $8000 \mathrm{~m}^{3}(1 \%)$ is in the subaerial beach. 


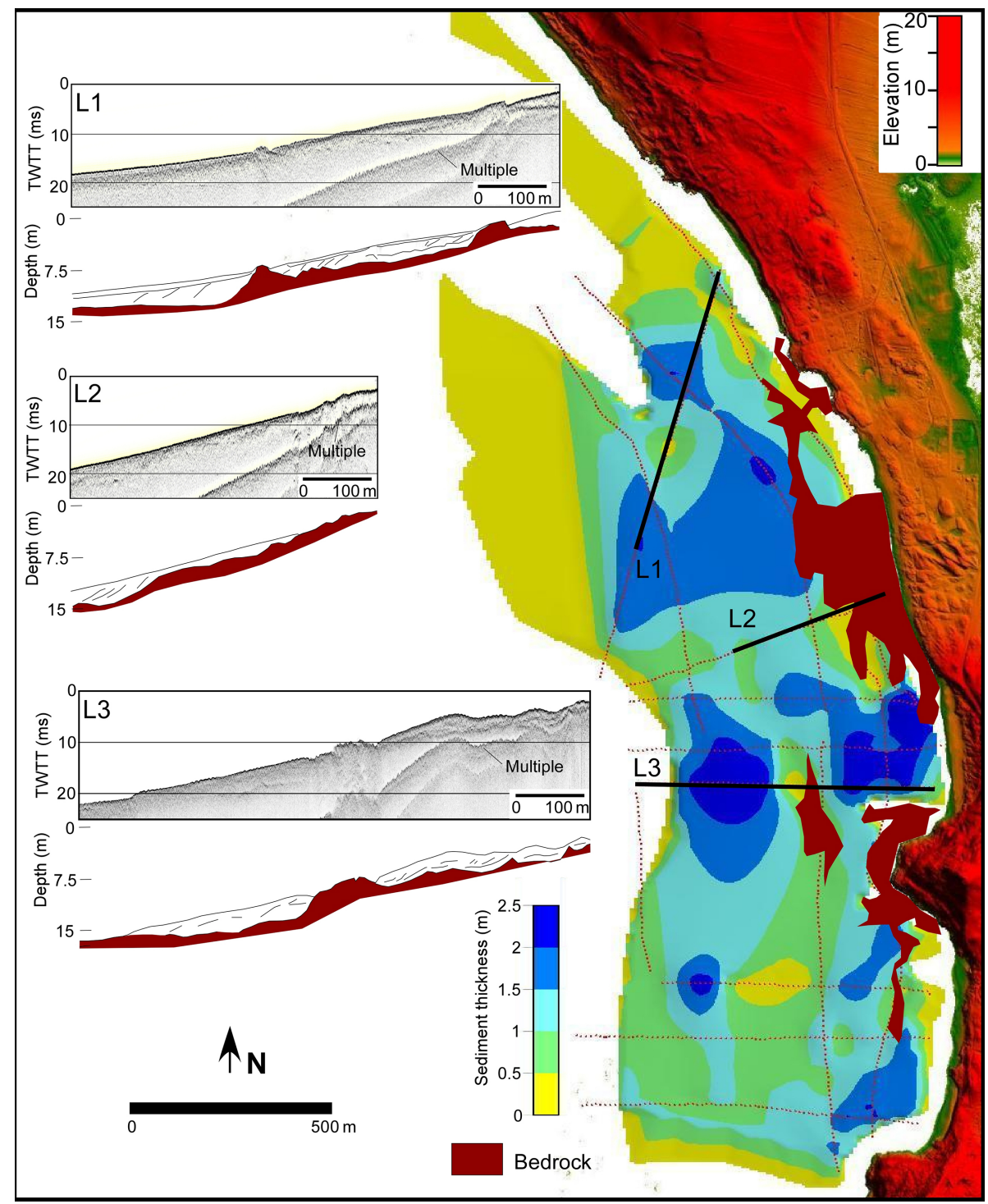

Figure 5. Very-high-resolution seismic profiles of offshore deposits. Representative seismic sections are shown with the derived stratigraphy (L1, L2 and L3). The contour map represents the thickness of sediments in the offshore area.

The total sediment mass was estimated at $3797000 \pm$ $404000 \mathrm{t}$. The total amount of modern bioclastic sediments is $1961000 \pm 205000 \mathrm{t}$. Considering a time span of sediment deposition of 43 centuries, based on the oldest radiocarbon dating of modern bioclastic grains (Table 1), we can estimate the deposition rates of MBGs. The total deposition rate is $46000 \pm 5000$ t century $^{-1}$, mainly in the coastal wedge $(85 \%)$ and dunes $(15 \%)$.

The sediment production from the coastal carbonate factories (Posidonia oceanica meadows and photophilic algal communities) was computed by multiplying the carbonate production rates per surface unit reported in previous studies (Serrano et al., 2012; De Falco et al., 2008; Canals and Ballesteros, 1997) per the surface area occupied by those ecosystems, based on seabed mapping (Fig. 1). The surface area of $P$. oceanica meadows was limited by the bathymetric contour line of $15 \mathrm{~m}$, which is the deeper limit of the coastal wedge, assuming that sediment transport from the carbonate factories to the beach was mainly driven by longshore currents. The total carbonate production rate from coastal ecosystems was estimated at 132000-307000 tcentury $^{-1}$, with $P$. oceanica meadows accounting for $76-90 \%$ of total production. The deposition rate of modern bioclastic sediment in the beach system corresponds to $15-34 \%$ of the carbonate production rate of the adjacent coastal ecosystems, assuming that the sediments were vertically well mixed. This assumption is particularly reliable for the coastal wedge, which accounts for the greater portion of sediment mass of the beach-dune system. Indeed the coastal wedge was char- 
Table 2. The sediment budget of the beach-dune system compartments.

\begin{tabular}{|c|c|c|c|c|}
\hline \multicolumn{2}{|c|}{ Variable description } & \multirow{2}{*}{$\begin{array}{l}\text { Unit } \\
\mathrm{m}^{3} \\
\mathrm{~m}^{3} \\
\mathrm{~m}^{3} \\
\mathrm{~m}^{3}\end{array}$} & \multirow{2}{*}{$\begin{array}{l}\text { Value } \\
330000 \pm 47000 \\
22000 \pm 8000 \\
1667000 \pm 160000 \\
2019000 \pm 215000\end{array}$} & \multirow{2}{*}{$\begin{array}{l}\text { Reference - method } \\
\text { Lidar data } \\
\text { Seismic and/or multibeam data }\end{array}$} \\
\hline Sediment volumes & $\begin{array}{l}\text { Dunes } \\
\text { Subaerial beach } \\
\text { Coastal wedge } \\
\text { Total }\end{array}$ & & & \\
\hline \multicolumn{2}{|c|}{$\begin{array}{c}\text { Porosity of sands } \\
\text { Density of dry sediments }\end{array}$} & $\begin{array}{l}\text { Adim } \\
\mathrm{tm}^{-3}\end{array}$ & $\begin{array}{l}0.30 \\
1.88\end{array}$ & \\
\hline Sediment mass & $\begin{array}{l}\text { Dunes } \\
\text { Subaerial beach } \\
\text { Coastal wedge } \\
\text { Total }\end{array}$ & $\begin{array}{l}t \\
t \\
t \\
t\end{array}$ & $\begin{array}{l}619000 \pm 88000 \\
41000 \pm 15000 \\
3137000 \pm 301000 \\
3797000 \pm 404000\end{array}$ & \\
\hline Mass of modern bioclastic sediments & $\begin{array}{l}\text { Dunes } \\
\text { Subaerial beach } \\
\text { Coastal wedge } \\
\text { Total }\end{array}$ & $\begin{array}{l}t \\
t \\
t \\
t\end{array}$ & $\begin{array}{l}285000 \pm 41000 \\
14000 \pm 5000 \\
1663000 \pm 160000 \\
1961000 \pm 205000\end{array}$ & Petrographic analysis \\
\hline \multicolumn{2}{|c|}{ Time span of sediment deposition } & Centuries & 43 & Calibrated ${ }^{14} \mathrm{C}$ dating \\
\hline $\begin{array}{l}\text { Deposition rate of modern } \\
\text { bioclastic sediments }\end{array}$ & $\begin{array}{l}\text { Dunes } \\
\text { Subaerial beach } \\
\text { Coastal wedge } \\
\text { Total }\end{array}$ & $\begin{array}{l}t_{\text {century }}{ }^{-1} \\
\text { t century }^{-1} \\
\text { t century }^{-1} \\
\text { t century }^{-1}\end{array}$ & $\begin{array}{l}7000 \pm 1000 \\
300 \pm 100 \\
39000 \pm 4000 \\
46000 \pm 5000\end{array}$ & \\
\hline \multicolumn{2}{|c|}{$\begin{array}{l}\text { Surface of } P \text {. oceanica meadows } \\
\text { Surface of photophilic algae }\end{array}$} & $\begin{array}{l}\mathrm{m}^{2} \\
\mathrm{~m}^{2}\end{array}$ & $\begin{array}{l}2624000 \\
1119000\end{array}$ & Seabed mapping \\
\hline Carbonate production rates & $\begin{array}{l}\text { Posidonia oceanica } \\
\text { Photophilic algae }\end{array}$ & $\begin{array}{l}\mathrm{g} \mathrm{DW} \mathrm{m}^{-2} \mathrm{yr}^{-1} \\
\mathrm{~g} \mathrm{DW} \mathrm{m}^{-2} \mathrm{yr}^{-1}\end{array}$ & $\begin{array}{l}493 \pm 15(390 / 1047) \\
289\end{array}$ & $\begin{array}{l}\text { Serrano et al. (2012), } \\
\text { De Falco et al. (2008) } \\
\text { Canals and Ballesteros (1997) }\end{array}$ \\
\hline $\begin{array}{l}\text { Mass of biogenic carbonate produced } \\
\text { by coastal ecosystems }\end{array}$ & $\begin{array}{l}\text { Posidonia oceanica } \\
\text { Photophilic algae } \\
\text { Total }\end{array}$ & $\begin{array}{l}\text { t century }^{-1} \\
\text { t century }^{-1} \\
\text { t century }^{-1}\end{array}$ & $\begin{array}{l}129000 \pm 4000(102000 / 275000) \\
32000 \\
162000 \pm 4000(135000-307000)\end{array}$ & \\
\hline \multicolumn{2}{|c|}{ Fraction of biogenic sediment delivered to the beach } & $\begin{array}{l}\text { Mass } \% \text { of carbonate } \\
\text { production }\end{array}$ & $28 \%(15 \% / 34 \%)$ & \\
\hline
\end{tabular}

acterised by a thin sediment layer (maximum $2.5 \mathrm{~m}$ ), which is frequently reworked, particularly in the surf zone.

\section{Discussion}

The results of our study show that the formation and evolution of the San Giovanni beach-dune system is controlled by a combination of several factors, including the availability of heterogeneous sediments resulting from the reworking of relict sediments and the production of biogenic sediments from coastal carbonate factories.

The San Giovanni beach-dune system is composed of mixed bioclastic and relict sediments deriving from various sources. The relict sediments include siliciclastic grains and biogenic carbonate (sensu Rivers et al., 2007). The provenance of the siliciclastic grains is complex, as they may have derived from either the reworking of relict sediments during barrier rollover following sea level rise, or from the erosion of cliffs located along the San Giovanni embayment. The biogenic relict sediments can be interpreted as Pleistocene sediments reworked and transported onshore (Rivers et al.,
2007; James, 1997). Those grains were exposed to meteoric conditions for a period of time and were then submerged once more, and they can thus be attributed to the last interglacial period. Relict grains constitute a large portion of the offshore sediments, whereas the beach-dune sediments are mainly composed of modern biogenic carbonates.

The system has also received a large input of modern bioclastic grains derived from sediment production by presentday carbonate factories. The biogenic carbonates are mainly composed of rhodophytes, molluscs and bryozoans. This association is typical of sediments produced by $P$. oceanica ecosystems, which are the main ecosystem producers of carbonate sediments in the infralittoral zone of the Mediterranean (Vacchi et al., 2016; De Falco et al., 2011; Canals and Ballesteros, 1997). The skeletal components of biogenic sediments associated with the meadows are mainly composed of molluscs, red algae, foraminifers, bryozoans and echinoids (Jeudy de Grissac and Boudouresque, 1985; Blanc and Jeudy de Grissac, 1989; Fornós and Ahr, 1997). Carbonate sediments produced in $P$. oceanica meadows are mostly trapped inside them, but we have demonstrated that a significant pro- 

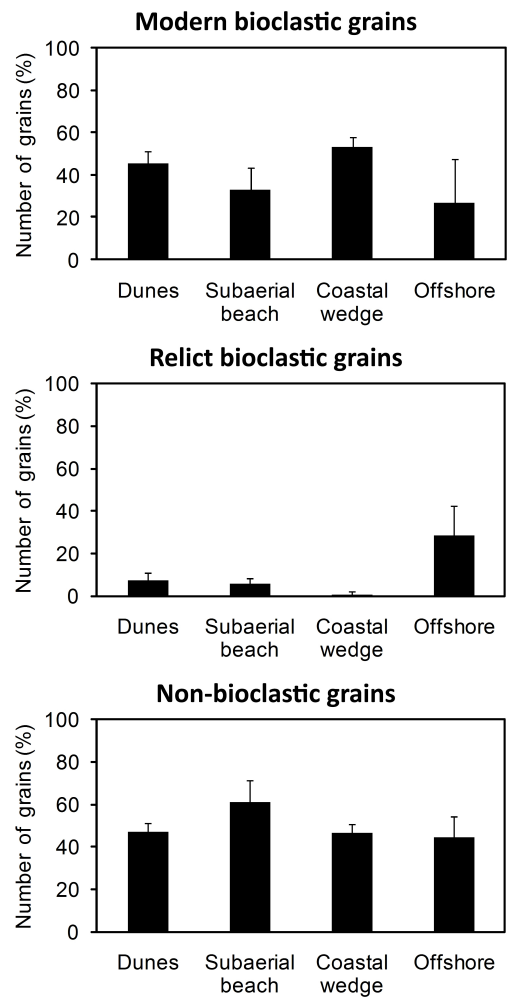

Figure 6. Percentage of different grain types in the San Giovanni beach-dune system compartments. Modern bioclastic, relict and non-bioclastic grains.

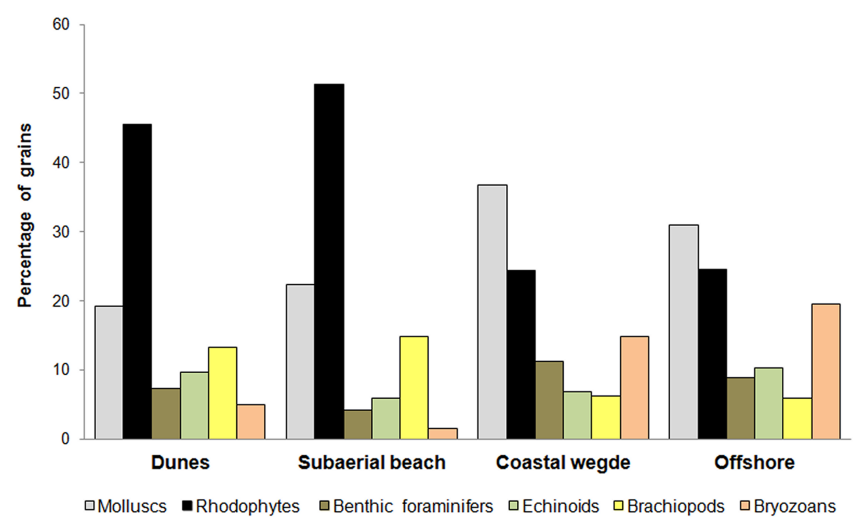

Figure 7. Distribution of bioclastic components in the San Giovanni beach-dune system compartments.

portion, estimated at 15 to $34 \%$, is exported outside the upper bathymetric limit towards the shoreface due to wave action.

This is the first study to quantify the contribution of biogenic sediments produced in $P$. oceanica meadows and in photophilic algal communities to the beach sediment budget.

A sediment budget is an evaluation of sediment gains and losses, or sources and sinks, within a specified cell or in a series of connected cells over a given time period. The algebraic difference between sediment sources and sinks in each cell, and hence for the entire sediment budget, must equal the rate of change in sediment volume occurring within that region (Rosati, 2005).

The production of biogenic carbonate by coastal ecosystems, the deposition rates and the schematic sediment transport pathways for the San Giovanni beach are shown in Fig. 9. Coastal ecosystems, to which the main contributor is Posidonia oceanica seagrass meadows, constitute a major source of sediments for the beach, with a net contribution of $46000 \pm 5000$ t century $^{-1}$, equivalent to $\sim 26000 \mathrm{~m}^{3}$ century ${ }^{-1}, 26000 \mathrm{~m}^{3}$ representing $\sim 1.2 \%$ of the current total beach-dune sediment volume. In other words, this beach has a positive budget, with an increase in volume over the long term, which is partially due to biogenic sand nourishment from a biological source. However, only a fraction ( $28 \%$ on average) of the biogenic sediment produced inside the coastal ecosystems is delivered to the beach. The remaining fraction of sediment is transported outside the beach system, trapped inside the ecosystems (De Falco et al., 2000, 2008, 2011; Serrano et al., 2012) or consumed by the process of carbonate grain alteration (López et al., 2016).

The contribution to the beach sediment budget represents a further ecosystem service provided by $P$. oceanica. Vassallo et al. (2013) estimated the value of the main ecosystem services provided by $P$. oceanica at $172 € \mathrm{~m}^{-2} \mathrm{a}^{-1}$. The authors considered sediment retention by $P$. oceanica meadows to be their most important contribution, accounting for almost all of their value. This estimate is 2 orders of magnitude higher than the values proposed by other authors for other coastal biomes (de Groot et al., 2012; Costanza et al., 2014). The calculation made by Vassallo et al. (2013) is an exception and probably overestimates the sediment retained in the meadows $\left(5.19 \times 10^{4} \mathrm{~g} \mathrm{~m}^{-2} \mathrm{a}^{-1}\right)$, which is 50 times higher than the values estimated by other authors (Serrano et al., 2012; De Falco et al., 2000). Our data quantify not only the volumes of sediment retained in the meadows but also the proportion that is exported to the beach-dune system. This facilitates a more detailed evaluation of the respective ecosystem services provided by the seagrass than had previously been possible.

The dependence of the beach sediment budget on carbonate production associated with costal ecosystems has several implications for the adaptation of mixed and carbonate beaches to environmental changes, at both local and global levels. Seagrass ecosystems are often impacted by intense human activities that inevitably affect their distribution (Meinesz et al., 1991; Duarte, 2002). The combined effects of anthropogenic and natural disturbance lead to a global decline in seagrass meadows, with loss rates estimated at 2 to $5 \%$ per year (Waycott et al., 2009; Short et al., 2011). The decline in P. oceanica meadows has been reported in the Mediterranean Sea (Ardizzone et al., 2006; Boudouresque et al., 2009; Montefalcone et al., 2010), where many meadows have already been lost in recent decades (Bianchi and Morri, 2000; Leriche et al., 2006; Marbà et al., 1996). 


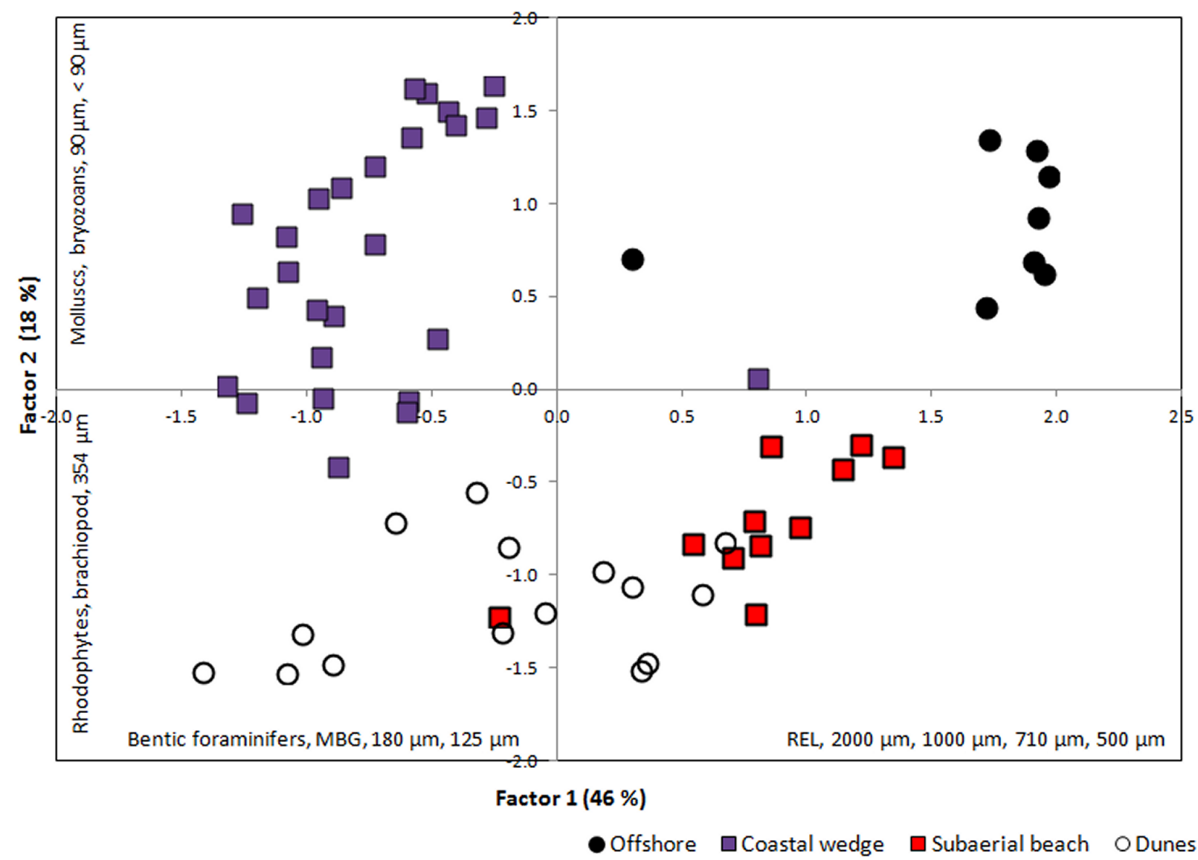

Figure 8. Results of factor analysis applied to the three beach-dune system compartments and offshore samples. Variables correlated with factor scores are indicated along the axes. REL is relict grains; MBG is modern bioclastic grain.

In the case of San Giovanni beach, the reduction of complete disappearance of the meadows would lead to the reduction of carbonate sediment production. Less sediment produced in coastal carbonate factories means less sediment being delivered to the beach, with a consequent possible change in the beach sediment budget from positive (beach accretion) to negative (beach erosion).

In relation to sea level rise, more complex effects are expected. The expected sea level rise by the year 2100 for the study area ranges from 0.54 to $1.3 \mathrm{~m}$ (Antonioli et al., 2017; De Falco et al., 2015). This will determine an adaptation of the whole coastal system. One of the expected consequences of sea-level rise is the retreat of shorelines and coastal erosion-related sediment redistribution due to waves and currents (Le Cozannet et al., 2014). The landward retreat of the shoreline implies the creation of newly available space for sedimentation, which will be occupied by sediments derived from the winnowing of subaerial beach and dune sediments. At the same time, however, sea level rise will have an impact on seagrass meadows. Specifically, the existing seagrass beds will be located at greater depth, with a decrease in the amount of light reaching them. This will reduce plant productivity (Short and Neckels, 1999; Marba and Duarte, 1997) and hence biogenic carbonate sediment production and transport from coastal ecosystems to the beach. In addition, sea level rise will reduce the surface area of the seagrass meadows able to transfer biogenic carbonates to the coastal wedge and the beach.
Furthermore, the rate at which seagrass meadows colonise new areas is slower than what will be required in order to keep up with the expected pace of sea level rise. Colonisation can occur by seed or lateral expansion, but those processes are known to be very slow and to depend on external forcing (i.e. basin hydrodynamics) and internal species-specific traits (i.e. rhizome elongation rates and the rhizomes' angle of branching) (Boström et al., 2006). Model-based studies show that complete coverage of the seabed by $P$. oceanica can take more than 600 years (Kendrick et al., 2005).

Consequently, the time required for mixed beaches to adapt to sea level rise will be longer than that of beaches that are mostly nourished by riverine sediments since the systems will also be affected by a reduction of sediment input due to the changes occurring in coastal ecosystems.

\section{Conclusions}

The sediments of the San Giovanni beach-dune system are composed of mixed modern bioclastic and relict grains. This system is far from any terrestrial source of sediments and represents a good model for computing the contribution of modern biogenic carbonate sediments to the beach sediment budget. The system receives a considerable input of modern bioclastic grains from the presentday carbonate factories, particularly the $P$. oceanica seagrass meadows. The total deposition rate of modern bioclastic grains is $46000 \pm 5000$ tcentury $^{-1}$, equivalent to 


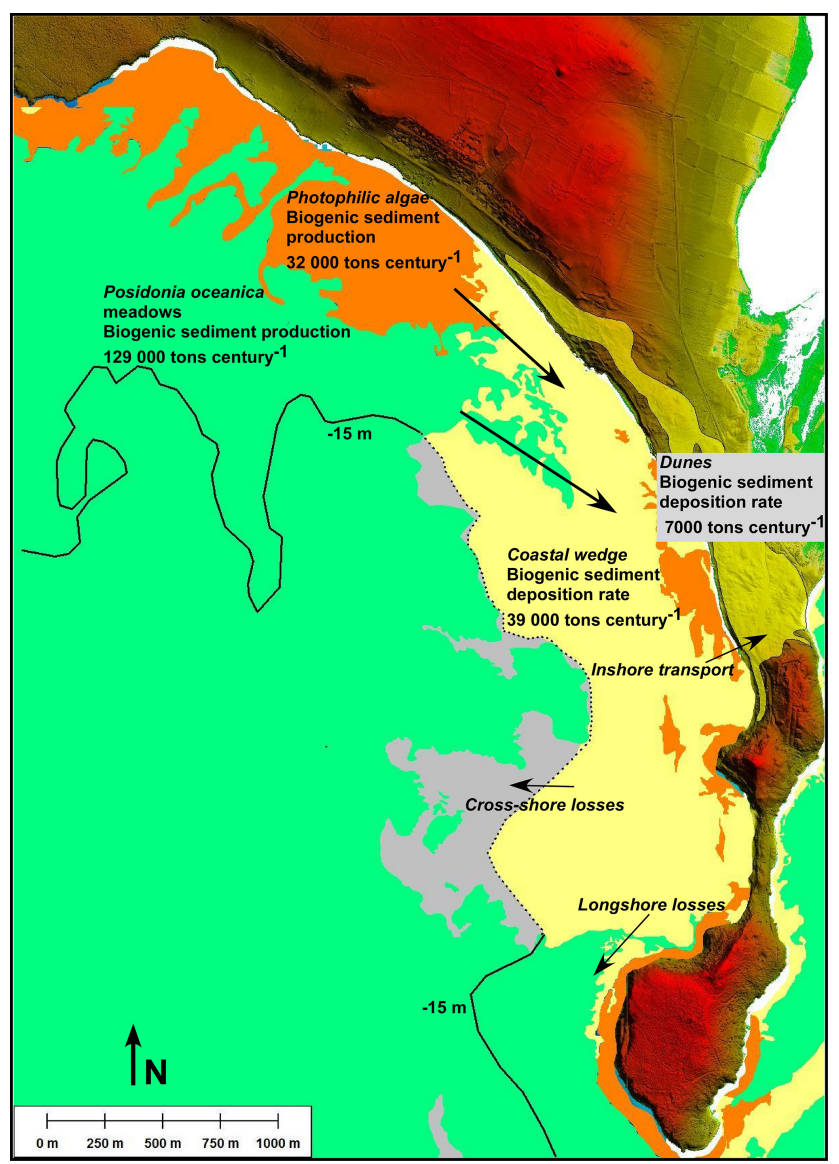

Figure 9. Schematic representation of the long-term biogenic sediment budget of the San Giovanni beach-dune system. Biogenic sediment production rates from coastal ecosystems, sediment transport pathways and biogenic sediment deposition rates throughout the beach-dune system.

$\sim 26000 \mathrm{~m}^{3}$ century ${ }^{-1}, 26000 \mathrm{~m}^{3}$ representing $\sim 1.2 \%$ of the current total beach-dune sediment volume.

The total rate of carbonate production from coastal ecosystems was estimated to be $132000-307000$ t century $^{-1}$, with Posidonia oceanica meadows accounting for $76-90 \%$ and photophilic algal communities accounting for the remainder $(24-10 \%)$. Modern bioclastic sediment produced within coastal ecosystems and delivered to the beach-dune system corresponds to $15-34 \%$ of total carbonate production.

Over a long period, modern bioclastic sediment produced in the nearshore carbonate factories has significantly contributed to the beach-dune system, forming a wide coastal wedge ( $85 \%$ of the total beach-dune system volume) and two extended dune fields ( $15 \%$ of the total beach volume).

The value of ecosystem services provided by $P$. oceanica (Vassallo et al., 2013) has mainly been associated with sediment retention by meadows. Our data can be considered as reference values for improving estimation of the value of the ecosystem service provided by Posidonia oceanica meadows in relation to beach sediment budgets.

The dependence of the beach sediment budget on carbonate production associated with coastal ecosystems has several implications for the adaptation of mixed and carbonate beaches to environmental changes, at both local and global levels.

The reduction or complete disappearance of the meadows due to local impacts would lead to the reduction of carbonate sediment production, with a consequent possible change in the beach sediment budget from positive (beach accretion) to negative (beach erosion).

Taking into account the sea level rise expected in the near future, the existing seagrass beds will be located at greater depth, with lower biogenic carbonate sediment production and transport from coastal ecosystems to the beach. The long time needed by $P$. oceanica meadows to colonise new areas will slow the rate of adaptation of such systems to the modified sea level conditions.

Data availability. Data are available at http://sk.oristano.iamc.cnr. it/maps/285 (De Falco et al., 2017).

\section{The Supplement related to this article is available online at https://doi.org/10.5194/bg-14-3191-2017-supplement.}

Competing interests. The authors declare that they have no conflict of interest.

Acknowledgements. We are grateful to the director of the Penisola del Sinis Isola di Mal di Ventre MPA for providing the boat for sampling. George Metcalf revised the English text.

Edited by: Christoph Heinze

Reviewed by: Mark Rowe and one anonymous referee

\section{References}

Acquaro, E.: Tharros, Cartagine di Sardegna, Rendiconti Accademia Lincei, 6, 523-541, 1995.

Andreucci, S., Pascucci, V., Murray, A. S., and Clemmensen, L. B.: Late Pleistocene coastal evolution of San Giovanni di Sinis, west Sardinia (Western Mediterranean), Sediment. Geol., 216, 104 116, 2009.

Antonioli, F., Anzidei, M., Amorosi, A., Lo Presti, V., Mastronuzzi, G., Deiana, G., De Falco, G., Fontana, A., Fontolan, G., Lisco, S., Marsico, A., Moretti, M., Orrù, P. E., Sannino, G. M., Serpelloni, E., and Vecchio, A.: Sea-level rise and potential drowning of the Italian coastal plains: Flooding risk scenarios for 2100, Quaternary Sci. Rev., 158, 29-43, 2017. 
Ardizzone, G., Belluscio, A., and Maiorano, L.: Long-term change in the structure of a Posidonia oceanica landscape and its reference for a monitoring plan, Mar. Ecol.-Prog. Ser., 27, 299-309, 2006.

Balzano, A., De Falco, G., Simeone, S., Sulis, A., Antognarelli, F., Massaro, G., Satta, A., Cugusi, G., Oiras, M., and Ventroni, M.: Morfodinamica della spiaggia di San Giovanni del Sinis, in: La Rete per il monitoraggio delle spiagge, edited by: Abis, A., Campo, C., Careddu, M. B., and Deriu, M., 98-136, ISBN 9788874321322, 2013.

Barsanti, M., Calda, N., and Valloni, R.: The Italian coasts: a Natural Laboratory for the Quality Evaluation of Beach Replenishments, J. Coastal Res., SI 61, 1-7, 2011.

Bianchi, C. and Morri, C.: Marine biodiversity of the Mediterranean sea: situation, problems and prospects for future research, Mar. Pollut. Bull., 40, 367-376, 2000.

Bird, E.: Coastal geomorphology. An introduction, San Francisco, Wiley \& Sons, 2008

Blanc, J. J. and Jeudy de Grissac, A.: Reflexion sur la regression des herbiers a Posidonies, in: International workshop on Posidonia oceanica Meadows, Departements du Var e des Bouches di Rhone, GIS Posidonie Publisher, France, 2, 273-285, 1989.

Borg, J. A., Attrill, M. J., Rowden, A. A., Schembri, P. J., and Jones, M. B.: Architectural characteristics of two bed types of the seagrass Posidonia oceanica over different spatial scales, Estuar. Coast. Shelf S., 62, 667-678, 2005.

Boström, C., Jackson, E. L., and Simenstad, C. A.: Seagrass landscapes and their effects on associated fauna: a review, Estuar. Coast. Shelf S., 68, 383-403, 2006.

Boudouresque, C. F., Bernard, G., Pergent, G., Shili, A., and Verlaque, M.: Regression of Mediterranean seagrasses caused by natural processes and anthropogenic disturbances and stress: a critical review, Bot. Mar., 52, 395-418, 2009.

Campus, B., Devoti, D., Pranzini, E., Rossi, L., and Silenzi, S.: Morfologia e dinamica dei sedimenti di una cuspate foreland (spiaggia della Pelosa, Stintino, Sardegna), Atti del Convegno Nazionale di Maratea 15-17 maggio 2008 n.9 - maggio 2008, http://www.adb.basilicata.it/adb/pubblicazioni/vol9.asp, 2008.

Canals, M. and Ballesteros, E.: Production of carbonate particles be phytobentic communities on the Mallorcae Menorca shelf, northwestern Mediterranean Sea, Deep-Sea Res. Pt. II, 44, 611-629, 1997.

Como, S., Magni, P., Baroli, M., Casu, D., De Falco, G., and Floris, A.: Comparative analysis of macrofaunal species richness and composition in Posidonia oceanica, Cymodocea nodosa and leaf litter beds, Mar. Biol., 153, 1087-1101, 2008.

Corsini, S., Franco, L., Inghilesi, R., and Piscopia, R.: Atlante delle onde nei mari Italiani - Italian Waves Atlas. Roma, Italy: Roma: Agenzia per la Protezione dell'Ambiente e per i servizi Tecnici, 2006.

Costanza, R., de Groot, R., Sutton, P., van der Ploeg, S., Anderson, S. J., Kubiszewski, I., Farber, S., and Turner, K.: Changes in the global value of ecosystem services, Glob. Environ. Chang., 26, 152-158, 2014.

Cucco, A., Perilli, A., De Falco, G., Ghezzo, M., and Umgiesser, G.: Water circulation and transport timescales in the Gulf of Oristano, Chem. Ecol., 22 (Suppl. 1), 307-331, 2006.

De Falco, G. and Piergallini, G. (Eds.): Mare, Golfo, Lagune - Studi e ricerche, Editrice S’Alvure (Oristano, Italy), 205 pp., 2003.
De Falco, G., Ferrari, S., Cancemi, G., and Baroli, M.: Relationships between sediment distribution and Posidonia oceanica seagrass, Geomarine Letters, 20, 50-57, 2000.

De Falco, G., Molinaroli, E., Baroli, M., and Bellacicco, S.: Grain size and compositional trends of sediments from Posidonia oceanica meadows to beach shore, Sardinia, Western Mediterranean, Coast. Shelf S., 58, 299-309, 2003.

De Falco, G., Baroli, M., Cucco, A., and Simeone, S.: Intrabasinal conditions promoting the development of a biogenic carbonate sedimentary facies associated with the seagrass Posidonia oceanic, Cont. Shelf Res., 28, 797-812, https://doi.org/10.1016/j.csr.2007.12.014, 2008.

De Falco, G., De Muro, S., Batzella, T., and Cucco, A.: Carbonate sedimentation and hydro-dynamical pattern on a modern temperate shelf: the strait of Bonifacio (western Mediterranean), Estuar. Coast. Shelf S., 93, 14-26, 2011.

De Falco, G., Antonioli, F., Fontolan, G., Lo Presti, V., Simeone, S., and Tonielli, R.: Early cementation and accommodation space dictate the evolution of an overstepping barrier system during the Holocene, Mar. Geol., 369, 52-66, 2015.

De Falco et al.: Data Repository De Falco et al. 2017 Biogeosciences, 14, 1-15, 2017, http://sk.oristano.iamc.cnr.it/maps/285, 30 June 2017.

de Groot, R., Brander, L., van der Ploeg, S., Costanza, R., Bernard, F., Braat, L., Christie, M., Crossman, N., Ghermandi, A., Hein, L., Hussain, S., Kumar, P., McVittie, A., Portela, R., Rodriguez, L.C., ten Brink, P., and van Beukering, P.: Global estimates of the value of ecosystems and their services in monetary units, Ecosystem Services, 1, 50-61, 2012.

De Muro, S. and De Falco, G. (Eds.): Manuale per la gestione delle spiagge: studi, indagini ed esperienze sulle spiagge sarde e corse, Cagliari: CUEC Ed., ISBN: 978-88-8467-629-0, 367 pp., 2010.

De Muro, S., Ibba, A., and Kalb, C.: Morpho-sedimentology of a Mediterranean microtidal embayed wave dominated beach system and related inner shelf with Posidonia oceanica meadows: the SE Sardinian coast, Journal of Maps, 12, 558-572, 2016.

Duarte, C. M.: The future of seagrass meadows, Environ. Conserv., 29, 192-206, 2002.

Duarte, C. M., Losada, I. J., Hendriks, I. E., Mazarrasa, I., and Marbà, N.: The role of coastal plant communities for climate change mitigation and adaptation, Nat. Climate Change, 3, 961968, 2013.

Flügel, E. (Ed.): Microfacies Analysis of Limestones, Berlin Heidelberg, Springer Verlag, 1982.

Fornós, J. J. and Ahr, W. M.: Temperate Carbonates on a Modern, Low-Energy, Isolated Ramp: The Balearic Platform, Spain. J. Sediment. Res. B, 67, 364-373, 1997.

Fornós, J. J. and Ahr, W. M.: Present-day temperate carbonate sedimentation on the Balearic Platform, western Mediterranean: compositional and textural variation along a low-energy isolated ramp, Geological Society, London, Special Publications, 255, 71-84, 2006.

Gacia, E., Duarte, C. M., Marbà, N., Terrados, J., Kennedy, H., Fortes, M. D., and Tri, N. H.: Sediment deposition and production in SE-Asia seagrass meadows. Estuarine, Coast. Shelf Sci., 56, 909-919, 2003.

Giakoumi, S., Sini, M., Gerovasileiou, V., Mazor, T., Beher, J., Possingham, H. P., Abdulla, A., Cinar, M. E., Dendrinos, P., Gucu, A. C., Karamanlidis, A. A., Rodic, P., Panayotidis, P., 
Taskin, E., Jaklin, A., Voultsiadou, E., Webster, C., Zenetos, A., and Katsanevakis, S.: Ecoregion-based conservation planning in the Mediterranean: dealing with large-scale heterogeneity, PLOS ONE, 8, 1-15, https://doi.org/10.1371/journal.pone.0076449, 2013.

Gómez-Pujol, L., Roig-Munar, F. X., Fornós, J. J., and Balaguer, P. Mateu, J.: Provenance-related characteristics of beach sediments around the island of Menorca, Balearic Islands (western Mediterranean), Geo-Mar. Lett., 33, 195-208, https://doi.org/10.1007/s00367-012-0314-y, 2013.

Harney, J. N. and Fletcher III, C. H.: A budget of carbonate framework and sediment production, Kailua Bay, Oahu, Hawaii, J. Sediment. Res., 73, 856-868, 2003.

James, N. P.: The cool-water carbonate depositional realm, in: CoolWater Carbonates, edited by: James, N. P. and Clarke, J. A. D., SEPM Special Publication, 56, 1-22, 1997.

Jeudy de Grissac, A. and Boudouresque, C. F.: Rôles des herbiers de phanérogames marines dans les mouvements des sédiments côtiers: les herbiers à Posidonia oceanica, Colloque francojaponais Oceanographie, Marseille, 16-21, 143-151, 1985.

Kendrick, G. A., Marba, N., and Duarte, C. M.: Modelling formation of complex topography by the seagrass Posidonia oceanica, Estuar. Coast. Shelf S., 65, 717-725, 2005.

Le Cozannet, G., Garcin, M., Yates, M., Idier, D., and Meyssignac, B.: Approaches to evaluate the recent impacts of sea-level rise on shoreline changes, Earth-Sci. Rev., 138, 47-60, 2014.

Leriche, A., Pasqualini, V., Boudouresque, C. F., Bernard, G., Bonhomme, P., Clabaut, P., and Denis, J.: Spatial, temporal and structural variations of a Posidonia oceanica seagrass meadow facing human activities, Aquat. Bot., 84, 287-293, 2006.

López, M., López, I., Aragonés, L., Serra, J. C., and Esteban, V.: The erosion on the east coast of Spain: Wear of particles, mineral composition, carbonates and Posidonia oceanica, Sci. Total Environ., 572, 487-497, 2016.

Marbà, N. and Duarte, C. M.: Interannual changes in seagrass (Posidonia oceanica) growth and environmental change in the Spanish Mediterranean littoral zone, Limnol. Oceanogr., 42, 800-810, 1997.

Marbà, N., Duarte, C. M., Cebrian, J., Gallegos, M. E., Olesen, B., and Sand-Jensen, K.: Growth and population dynamics of Posidonia oceanica on the Spanish Mediterranean Coast: Elucidating seagrass decline, Mar. Ecol.-Prog. Ser., 137, 203-213, 1996.

Mateu-Vicens, G., Brandano, M., Gaglianone, G., and Baldassarre, A.: Seagrass-meadow sedimentary facies in a mixed siliciclasticcarbonate temperate system in the Tyrrhenian Sea (Pontinian Islands, Western Mediterranean), J. Sediment. Res., 82, 451-463, https://doi.org/10.2110/jsr.2012.42, 2012.

Mazarrasa, I., Marbà, N., Lovelock, C. E., Serrano, O., Lavery, P. S., Fourqurean, J. W., Kennedy, H., Mateo, M. A., Krause-Jensen, D., Steven, A. D. L., and Duarte, C. M.: Seagrass meadows as a globally significant carbonate reservoir, Biogeosciences, 12, 4993-5003, https://doi.org/10.5194/bg-12-4993-2015, 2015.

Meinesz, A., Lefevre, J. R., and Astier, J. M.: Impact of coastal development on the infralittoral zone along the Southeastern Mediterranean shore of continental France, Mar. Pollut. Bull., 23, 343-347, 1991.

Milliman, J. D. and Droxler, A. W.: Neritic and pelagic carbonate sedimentation in the marine environment: ignorance is not bliss, Geol. Rundsch., 85, 496-504, 1996.
Montefalcone, M., Albertelli, G., Morri, C., and Bianchi, C. N.: Pattern of wide-scale substitution within Posidonia oceanica meadows of NW Mediterranean Sea: invaders are stronger than natives, Aquat. Conserv., 20, 507-515, 2010.

Nelson, C. S.: An introductory perspective on nontropical shelf carbonates, Sediment. Geol., 60, 3-14, 1988.

Pasqualini, V., Pergent-Martini, C., Clabaut, P., and Pergent, G.: Mapping of Posidonia oceanica using aerial photographs and side scan sonar: application off the Island of Corsica (France), Estuar. Coast. Shelf S., 47, 359-367, 1998.

Reimer, P. J., Bard, E., Bayliss, A., Beck, J. W., Blackwell, P. G., Bronk Ramsey, C., Buck, C. E. Cheng, H., Edwards, R. L., Friedrich, M., Grootes, P. M., Guilderson, T. P., Haflidason, H., Hajdas, I., Hattè, C., Heaton, T. J., Hoffmann, D. L., Hogg, A. G., Hughen, K. A., Kaiser, K. F., Kromer, B., Manning, S. W., Niu, M., Reimer, R. W., Richards, D. A., Scott, E. M., Southon, J. R., Staff, R. A., Turney, C. S. M., and van der Plicht, J.: IntCal13 and Marine 13 radiocarbon age calibration curves 0-50,000 years cal BP, Radiocarbon, 55, 1869-1887, https://doi.org/10.2458/azu_js_rc.55.16947, 2013.

Rivers, J., James, N. P., Kyser, T. K., and Bone, Y.: Genesis of palimpsest cool-water carbonate sediment on the continental margin of Southern Australia, J. Sediment. Res., 77, 480-494, https://doi.org/10.2110/jsr.2007.046, 2007.

Rosati, J. D.: Concepts in sediment budgets, J. Coastal Res., 21, 307-322, 2005.

Ryan, D. A., Brooke, B. P., Collins, L. B., Spooner, M. I., and Siwabessy, P. J. W.: Formation, morphology and preservation of high energy carbonate lithofacies: evolution of the coolwater Recherche Archipelago inner shelf, south-western Australia, Sediment. Geol., 207, 41-55, 2008.

Sanderson, P. G. and Eliot, I.: Compartmentalisation of beachface sediments along the southwestern coast of Australia, Mar. Geol., 162, 145-164, 1999.

Serrano, O., Mateo, M. A., Renom, P., and Julià, R.: Characterization of soils beneath a Posidonia oceanica meadow, Geoderma, 185, 26-36, 2012.

Short, A. D: Handbook of Beach and Shoreface Morphodynamics, John Wiley \& Sons Ltd., England, 379 pp., ISBN: 047196570 7, 1999.

Short, A. D.: The Distribution and Impact of Carbonate Sands on Southern Australian Beach-Dune Systems, in: Carbonate Beaches, edited by: Magoon, O. T., Robbins, L. L., and Ewing, L., Proceedings ASCE, 236-250, 2000.

Short, A. D.: Sediment transport around Australia - Sources, mechanisms, rates, and barrier forms, J. Coast. Res., 26, 395-402, 2010.

Short, F. T. and Neckels, H. A.: The effects of global climate change on seagrasses, Aquat. Bot., 63, 169-196, 1999.

Short, F. T., Polidoro, B., Livingstone, S. R., Carpenter, K. E., Bandeira, S., Bujang, J. S., Calumpong, H. P., Carruthers, T. J. B., Coles, R. G., Dennison, W. C., Erftemeier, P. L. A., Fortes, M. D., Freeman, A. S., Jagtap, T. G., Kamal, A. H. M., Kendrick, G. A., Kenworthy, W. J., La Nafie, Y. A., Nasution, I. M., Orth, R. J., Prathep, A., Sanciangco, J. C., van Tussenbroek, B., Vergara, S. G., Waycott, M., and Zieman, J. C.: Extinction risk assessment of the world's seagrass species, Biol. Conserv., 144, 1961-1971, 2011. 
Simeone, S. and De Falco, G.: Morphology and composition of beachcast Posidonia oceanica litter on beaches with different exposures, Geomorphology, 151, 224-233, 2012.

Simeone, S., De Muro, S., and De Falco, G.: Seagrass berm deposition on a Mediterranean embayed beach, Estuarine, Coast. Shelf Sci., 135, 171-181, 2013.

Simeone, S., De Falco, G., Quattrocchi, G., and Cucco, A.: Morphological changes of a Mediterranean beach over one year (San Giovanni Sinis, western Mediterranean), J. Coast. Res., SI 70, 217-222, 2014.

Talma, A. S. and Vogel, J. C.: A simplified approach to calibrating ${ }^{14} \mathrm{C}$ dates, Radiocarbon, 35, 317-322, 1993.

Tecchiato, S., Collins, L., Parnum, I., and Stevens, A.: The influence of geomorphology and sedimentary processes on benthic habitat distribution and littoral sediment dynamics: Geraldton, Western Australia, Mar. Geol., 359, 148-162, 2015.

Tigny, V., Ozer, A., De Falco, G., Baroli, M., and Djenidi, S.: Relationship between the Evolution of the Shoreline and the Posidonia oceanica meadow limit in a Sardinian Coastal Zone, J. Coast. Res., 23, 787-793, 2007.

Vacchi, M., De Falco, G., Simeone, S., Montefalcone, M., Morri, C., Ferrari, M., and Nike Bianchi, C.: Biogeomorphology of the Mediterranean Posidonia oceanica seagrass meadows,. Earth Surf. Proc. Land., 42, 42-54, https://doi.org/10.1002/esp.3932, 2016.
Vassallo, P., Paoli, C., Rovere, A., Montefalcone, M., Morri, C., and Bianchi, C. N.: The value of the seagrass Posidonia oceanica: a natural capital assessment, Mar. Pollut. Bull., 75, 157-167, 2013.

Waycott, M., Duarte, C. M., Carruthers, T. J., Orth, R. J., Dennison, W. C., Olyarnik, S., Calladine, A., Fourqurean, J. W., Heck Jr., K. L., Hughes, A. R., Kendrick, G. A., Kenworthy, W. J., Short, F. T., and Williams, S. L.: Accelerating loss of seagrasses across the globe threatens coastal ecosystems, P. Natl. Acad. Sci. USA, 106, 12377-12381, 2009.

Yamano, H., Kayanne, H., Matsuda, F., and Tsuji, Y.: Lagoonal facies, ages, and sedimentation in three atolls in the Pacific, Mar. Geol., 185, 233-247, 2002.

Yamano, H., Cabioch, G., Pelletier, B., Chevillon, C., Tachikawa, H., Lefêvre, J., and Marchesiello, P.: Modern carbonate sedimentary facies on the outer shelf and slope around New Caledonia, Isl. Arc, 24, 4-15, 2015. 